\title{
Are Human Genes Patentable?
}

\author{
Dan L. Burk
}

Published online: 20 September 2013

(C) Max Planck Institute for Intellectual Property and Competition Law, Munich 2013

On June 13, 2013 the United States Supreme Court delivered its long-anticipated opinion in Association for Molecular Pathology v. Myriad ${ }^{1}$ a decision addressing the question posed by the Court to the parties, "Are human genes patentable?", As has already been widely reported in the popular press, in a relatively short and essentially unanimous opinion authored by Justice Thomas, the Court held DNA sequences extracted from human cells to constitute products of nature, outside patentable subject matter. But what has been less widely reported is the simultaneous holding that other human gene sequences, entailing equivalent information, remain within patentable subject matter. The reasoning behind this distinction is puzzling and contradictory, and leaves the law in this area far more confused and uncertain than before the Court undertook its answer to the gene patenting question.

Two types of claimed nucleotide sequences were at issue in the case: genomic or gDNA that was extracted and isolated from human cells, and complementary or cDNA that is produced in a laboratory procedure called reverse transcription, using messenger RNA as a template. A three-judge panel of the intermediate Federal Circuit court of appeal had unanimously found the cDNA to be the patent eligible product of human intervention, but the Federal Circuit judges split over the patentability of the isolated gDNA molecules. ${ }^{3}$ The principal opinion, written by Judge Lourie, found the gDNA molecules to be patentable subject matter due to their chemical separation from the chromosome in which they were naturally

\footnotetext{
1569 U.S. (2013).

2133 S.Ct. 694 (2012) (granting certiorari).

3 Ass'n for Molecular Pathology v. U.S. Patent \& Trademark Office, 689 F.3d 1303, 1329 (Fed. Cir. 2012).
}

D. L. Burk $(\bowtie)$

Professor of Law

University of California, Irvine, 401 East Peltason Dr., Law 4800-N, Irvine, CA 92697-8000, USA

e-mail: dburk@law.uci.edu 
situated. A concurring opinion by Judge Moore argued that they constituted patentable subject matter due to the technical uses to which an isolated molecule could be put. A dissenting opinion by Judge Bryson rejected the gDNA as patentable subject matter, arguing that the molecules were not significantly different from the sequences found in nature.

These three rationales effectively constitute the familiar patentability criteria of novelty, utility, and non-obviousness. Judge Lourie believed the genomic DNA sequences to be patentable because they were new structures not previously described in the prior art; Judge Moore believed them to be patentable because they facilitated a new use; Judge Bryson believed them to unpatentable because they were not sufficiently inventive. As I have pointed out elsewhere, ${ }^{4}$ it is hardly surprising that these experienced judges resorted to filling the vacuum that is the products of nature doctrine with content from other patent criteria, since the products of nature doctrine has never had any content of its own.

On appeal, the Supreme Court largely agreed with Judge Bryson's position regarding gDNA as a product of nature. Although recognizing that the sequence as isolated by Myriad is a molecule that would not normally be found in nature, the Court deemed the claimed gene to be essentially identical, or at least equivalent, to the analogous sequence as it exists in a human chromosome. In this portion of the opinion the Court adopted the position that DNA coding sequences are unpatentable when the isolated and the native sequences are informationally indistinguishable. That is to say, if both the chromosomal and isolated genomic sequences code for the same gene product, this common function places the isolated sequence in the products of nature category.

But the court pivots away from this informational framework in the latter half of the opinion dealing with cDNA. There Justice Thomas reasoned that cDNA molecules may fall within patentable subject matter if they differ structurally from their native analogs. Specifically, the Court held that because the reverse transcription process produces a cDNA molecule that lacks the non-coding intervening sequences found in the native genomic sequence, the Myriad cDNA differs sufficiently from what is found in nature to constitute a human invention. This rationale is underscored by the Court's caveat that a cDNA molecule having a coding sequence identical to its chromosomal analog would likely not constitute a human invention.

This tension in the opinion between functional and structural rationales makes the decision at best inconsistent. At some level, specifying a particular nucleotide sequence $i$ s the specification of structure: the familiar "ATCG" notation for DNA is in fact a shorthand for a particular chemical structure, making it difficult to discern the difference that leads to different outcomes for gDNA and cDNA. Indeed, at one point the opinion seems to invite strategic characterization of gene sequences in structural terms. In rejecting Judge Lourie's rationale for the patentability of gDNA, the Supreme Court reasoned that because the molecules in the Myriad patent were not claimed in terms of severed covalent bonds, such structural changes could not

\footnotetext{
${ }^{4}$ Dan L. Burk, The Runcible Product of Nature Doctrine, SCOTUSBLOG, Feb. 4, 2013. http://www. scotusblog.com/2013/02/the-runcible-product-of-nature-doctrine/.
} 
differentiate them from the sequences found in nature. But this leaves the future claim drafter to wonder whether claims to an excised gDNA sequence might successfully be couched in terms describing the covalently truncated $5^{\prime}$ and $3^{\prime}$ terminal structures of the molecule, thus differentiating the molecule in a fashion the Court found lacking in Myriad's claims.

But perhaps the most puzzling aspect of the opinion is the absence of any reference to the Supreme Court's earlier opinion in Mayo v. Prometheus, which dealt with the patentability of a diagnostic method under the law of nature doctrine. There the court found that process claims to a method of correlating metabolic test results to a patient's treatment constituted an unpatentable claim to phenomena found in nature. On the basis of this ruling, the lower courts in the Myriad litigation unanimously agreed that Myriad's patent claims to diagnostic methods were unpatentable correlations of sequence information to a patient's propensity for cancer. Those diagnostic method claims never came before the Supreme Court, and remain invalid under the lower court rulings.

Mayo dealt with laws or principles of nature, but when the Myriad DNA product claims first came before the Supreme Court, they were remanded to the lower appellate court for reconsideration in light of the Mayo decision. A majority of the Federal Circuit panel found the Mayo decision inapposite to the Myriad DNA product claims. Yet, despite its order to reconsider the Myriad case in light of Mayo, the Supreme Court itself says nothing in Myriad about its Mayo holding. This leaves the relationship between products of nature and laws of nature in American patent law uncertain and undefined, especially given the Court's use of both functional and structural reasoning to reach differing conclusions regarding the patentability of cDNA and gDNA. While the Myriad decision confirms that there is a distinct product of nature doctrine, it leaves the substance of that doctrine, as well as its boundaries and application more uncertain than ever. 